\title{
Chronic fatigue and myalgia syndrome: mitochondrial and glycolytic studies in skeletal muscle
}

\author{
EDWARD BYRNE, IAN TROUNCE \\ From the St Vincent's Hospital, Melbourne, Australia
}

SUMmaRY Clinical and biochemical findings in skeletal muscle in 11 patients with chronic fatigue myalgia syndromes of unknown aetiology are reported. All patients had severe asthenia for from one to 10 years with greatly limited exercise capacity and protracted exhaustion after minor exercise. Diffuse myalgia was prominent and was exacerbated for hours to days after exercise. Assay of skeletal muscle carnitine, phosphorylase, all glycolytic enzymes and the mitochondrial marker enzymes monoamine oxidase, isocitrate dehydrogenase and cytochrome oxidase were normal. These findings lend no support to the presence of a major defect in muscle intermediary energy pathways in this syndrome.

Severe asthenia and myalgia of obscure aetiology and protracted course is a common problem and has been designated as post viral fatigue syndrome, ${ }^{1}$ epidemic myalgic encephalomyelitis, ${ }^{2}$ epidemic neuromyasthenia ${ }^{3}$ and Royal Free disease. Sporadic cases are more common than epidemic cases ${ }^{1}$ and there is considerable dispute as to whether this disorder has an organic or a psychogenic basis. ${ }^{145}$ Defects in intermediary muscle metabolism are well recognised as causes of both fatigability and myalgia. Mitochondrial deficiencies may be associated with prominent fatigability ${ }^{6-8}$ and exercise induced myalgia characterises disorders of glycogenolysis and glycolysis. $^{9-12}$

Although the clinical features of the chronic fatigue and myalgia syndrome differ from those of well established deficiences in intermediary energy metabolism, the possibility merits consideration that a subtle metabolic derangement may have a pathogenic role in this syndrome. Recent MRI studies have provided some support for this postulate. ${ }^{13}$ The possibility of a deficiency in intermediary energy pathways was explored in this study by assay of muscle glycolytic and mitochondrial marker enzymes, phosphorylase and carnitine in a group of 11 patients.

Address for reprint requests: Dr E Byrne, Neurology Department, St Vincent's Hospital, Fitzroy 3065 Australia.

Received 22 July 1986. Accepted 23 October 1986

\section{Patients and methods}

Patient selection and biopsy

Patients with chronic disabling asthenia and myalgia of obscure aetiology were selected for study. Patients were excluded if asthenia was not prominent, if myalgia and cramps were closely linked to heavy exercise only and if an alternate definite neurological diagnosis could be established. Eleven patients met these criteria. Muscle biopsy was performed on either the left deltoid or vastus lateralis muscle under local anaesthesia. Specimens were processed for electron microscopy and histochemistry in a standard way. ${ }^{8}$ Several blocks of 50-100 mg wet weight were rapidly frozen in liquid nitrogen immediately after biopsy and stored at $-70^{\circ} \mathrm{C}$ prior to studies.

Metabolic assays were also carried out in two control groups. Biopsy specimens were obtained from six consenting patients with no neuromuscular abnormalities who were undergoing orthopaedic procedures. The biopsy was taken from the vastus lateralis muscle in each case. The mean age of this patient group ( $79 \pm 9.6$ years) was significantly older than the myalgia group and muscle histology was not examined. The second control group comprised four patients with histological evidence of myopathic disorders (myositis, dystrophy).

\section{Biochemical methods}

Phosphorylase (PH) activity was assayed according to Bergmeyer, ${ }^{14}$ while glycolytic enzyme activities (hexokinase [HEX], phosphoglucose isomerase [PGI], phosphofructokinase [PFK], aldolase [ALD], triosephosphate isomerase [TIM], glyceraldehyde phosphate dehydrogenase [GDH], phosphoglycerate kinase [PGK], phosphoglyceromutase [PGM], enolase [ENL], pyruvate kinase [PK] and lactate dehydrogenase [LDH]) were measured in muscle homogenate after sonication by a modification of the 
method of Doery et al ${ }^{15}$ as previously described. ${ }^{16}$ Cytochrome oxidase activity was measured spectrophotometrically by following the decrease in absorbance of reduced cytochrome $\mathrm{C}$ at $550 \mathrm{~nm}^{8}$ and monoamine oxidase assayed by incubating muscle homogenate with $\left[{ }^{14} \mathrm{C}\right]$ tyramine followed by extraction of the labelled aldehyde product with butyl acetate and counting for $\left[{ }^{14} \mathrm{C}\right]$ by liquid scintillation. ${ }^{8}$ Isocitrate dehydrogenase (NADP dependent) activity was measured spectrophotometrically by a modification of the method of Wolfson and WilliamsAshman. ${ }^{17}$ Total muscle carnitine was assayed after alkaline hydrolysis by measuring $\left[{ }^{14} \mathrm{C}\right]$ acetyl carnitine formation after incubation of the sample with $\left[{ }^{14} \mathrm{C}\right]$ acetyl $\mathrm{CoA}$ and carnitine acetyl transferase. ${ }^{16}$

\section{Results}

\section{Clinical}

Clinical findings are shown in table 1. Protracted asthenia was present in all cases and general medical and neurological examination was normal. Persistent low grade myalgia at rest was present in all cases and 10 of the 11 cases noted a prolonged exacerbation of aching after exercise. Only five of the patients had symptoms suggestive of virus infection prior to the development of myalgia/asthenia and serological evi- dence of a specific infection was lacking in all of these. Routine muscle histochemistry revealed either no abnormality or mild type $2 b$ fibre atrophy in 10 of the 11 patients (Dr Xenia Dennett, Royal Children's Hospital). One patient had evidence of minicore change in several fibres. A detailed morphometric analysis of these specimens (Dr Dennett) will be reported separately. None of the patients was able to work or engage in physical sport. CK levels were normal in all patients except one where a moderately raised level was found in only one of several assays. Ischaemic exercise testing was carried out in nine of the 11 patients and revealed a normal lactate rise in all.

\section{Biochemical results}

Glycolytic enzyme and phosphorylase levels are shown in table 2, while carnitine and mitochondrial marker enzyme results are shown in table 3 . Levels for all enzymes assayed and for carnitine were well preserved for all patients with reference to both control groups. Cytochrome oxidase and most glycolytic enzyme levels were significantly higher in the disease control group and the fatigue myalgia group than in

Table 1 Clinical findings

\begin{tabular}{|c|c|c|c|c|c|c|c|c|c|}
\hline Patient & Age (yr) & Sex & Asthenia & Myalgia & $\begin{array}{l}\text { Exercise } \\
\text { exacerbation }\end{array}$ & $\begin{array}{l}\text { Antecedent } \\
\text { viral illness }\end{array}$ & $\begin{array}{l}\text { Muscle } \\
\text { tenderness }\end{array}$ & $\begin{array}{l}\text { Duration } \\
\text { symptoms }\end{array}$ & $\begin{array}{l}\text { Previous } \\
\text { occupation }\end{array}$ \\
\hline $\begin{array}{r}1 \\
2 \\
3 \\
4 \\
5 \\
6 \\
7 \\
8 \\
9 \\
10 \\
11\end{array}$ & $\begin{array}{l}31 \\
47 \\
42 \\
53 \\
50 \\
39 \\
25 \\
65 \\
30 \\
29 \\
23\end{array}$ & $\begin{array}{l}\mathbf{M} \\
\mathbf{M} \\
\mathbf{M} \\
\mathbf{M} \\
\mathbf{F} \\
\mathbf{M} \\
\mathbf{F} \\
\mathbf{F} \\
\mathbf{M} \\
\mathbf{F} \\
\mathbf{F}\end{array}$ & $\begin{array}{l}+ \\
++ \\
++ \\
++ \\
++ \\
++ \\
+ \\
++ \\
++ \\
++ \\
++\end{array}$ & $\begin{array}{l}++ \\
++ \\
+ \\
++ \\
++ \\
+ \\
++ \\
++ \\
+t \\
+ \\
++\end{array}$ & $\begin{array}{l}++ \\
++ \\
++ \\
++ \\
++ \\
++ \\
++ \\
++ \\
++ \\
++ \\
++\end{array}$ & $\begin{array}{l}- \\
- \\
? \\
? \\
? \\
? \\
- \\
? \\
-\end{array}$ & $\begin{array}{l}+ \\
++ \\
- \\
+ \\
- \\
+ \\
+ \\
- \\
- \\
-\end{array}$ & $\begin{array}{l}5 \text { years } \\
15 \\
1 \\
3 \\
10 \\
5 \\
4 \\
10 \\
7 \\
1 \cdot 5 \\
5\end{array}$ & $\begin{array}{l}\text { labourer } \\
\text { removalist } \\
\text { farmer } \\
\text { labourer } \\
\text { religious order } \\
\text { taxi driver } \\
\text { nurse } \\
\text { housewife } \\
\text { plasterer } \\
\text { housewife } \\
\text { student }\end{array}$ \\
\hline
\end{tabular}

+ mild; ++ moderate; +++ severe.

Table 2 Glycolytic enzymes

\begin{tabular}{|c|c|c|c|c|c|c|c|c|c|}
\hline \multirow[b]{2}{*}{ Enzyme } & \multicolumn{3}{|c|}{ Orthopaedic control group $(n=6)$} & \multicolumn{3}{|c|}{ Disease control group $(n=4)$} & \multicolumn{3}{|c|}{ Patient group $(n=11)$} \\
\hline & Mean & $S D$ & Range & Mean & $S D$ & Range & Mean & $S D$ & Range \\
\hline $\begin{array}{l}\text { PH } \\
\text { HEX } \\
\text { PGI } \\
\text { PFK } \\
\text { ALD } \\
\text { TIM } \\
\text { GDH } \\
\text { PGK } \\
\text { PGM } \\
\text { ENL } \\
\text { PK } \\
\text { LDH }\end{array}$ & $\begin{array}{l}28 \cdot 6 \\
1 \cdot 57 \\
159 \\
36 \cdot 7 \\
45 \cdot 2 \\
1074 \\
214 \\
161 \\
292 \\
140 \\
217 \\
174\end{array}$ & $\begin{array}{l}17 \cdot 0 \\
0 \cdot 66 \\
69 \cdot 5 \\
10 \cdot 1 \\
15 \cdot 5 \\
381 \\
127 \\
56 \cdot 7 \\
187 \\
50 \cdot 2 \\
100 \\
111\end{array}$ & $\begin{array}{l}13 \cdot 3-55 \cdot 0 \\
0 \cdot 93-2 \cdot 58 \\
100-281^{*} \\
24 \cdot 8-46 \cdot 0^{*} \\
28 \cdot 9-66 \cdot 0^{*} \\
714-1688^{*} \\
111-406^{*} \\
99 \cdot 0-232^{*} \\
125-546^{*} \\
71 \cdot 2-212^{*} \\
114-388^{*} \\
72 \cdot 6-316^{*}\end{array}$ & $\begin{array}{l}51 \cdot 2 \\
2 \cdot 09 \\
317 \\
59 \cdot 6 \\
90 \cdot 2 \\
2187 \\
427 \\
325 \\
671 \\
297 \\
519 \\
400\end{array}$ & $\begin{array}{l}14 \cdot 3 \\
0 \cdot 47 \\
60 \cdot 7 \\
12 \cdot 7 \\
21 \cdot 0 \\
494 \\
119 \\
74 \cdot 7 \\
219 \\
118 \\
158 \\
135\end{array}$ & $\begin{array}{l}29 \cdot 6-64 \cdot 7 \\
1 \cdot 55-2 \cdot 54 \\
266-400 \\
41 \cdot 5-71 \cdot 0 \\
67 \cdot 1-82 \cdot 8 \\
1490-2605 \\
268-549 \\
252-421 \\
422-809 \\
195-457 \\
348-730 \\
200-493\end{array}$ & $\begin{array}{l}43 \cdot 2 \\
2 \cdot 39 \\
294 \\
54 \cdot 6 \\
86 \cdot 3 \\
2076 \\
348 \\
311 \\
614 \\
249 \\
464 \\
347\end{array}$ & $\begin{array}{l}15 \cdot 4 \\
0 \cdot 51 \\
75 \cdot 3 \\
14 \cdot 9 \\
24 \cdot 9 \\
710 \\
102 \\
89 \cdot 5 \\
182 \\
60 \cdot 3 \\
147 \\
156\end{array}$ & $\begin{array}{l}25 \cdot 2-74 \cdot 8 \\
1 \cdot 79-3 \cdot 11 \\
194-465 \\
24 \cdot 5-76 \cdot 0 \\
46 \cdot 7-130 \\
1301-3614 \\
186-485 \\
239-500 \\
333-1008 \\
114-336 \\
319-787 \\
175-692\end{array}$ \\
\hline
\end{tabular}

*p $<0.05$ when means compared with both other groups (unpaired Student's $t$ test).

Figures show $\mu \mathrm{mol}$ substrate used $/ \mathrm{min} / \mathrm{g}$ muscle wet weight. 
Table 3 Mitochondrial marker enzyme activity and carnitine levels in patient and control groups

\begin{tabular}{|c|c|c|c|c|c|c|c|c|c|}
\hline & \multicolumn{3}{|c|}{$\begin{array}{l}\text { Orthopaedic } \\
\text { control group }(n=6)\end{array}$} & \multicolumn{3}{|c|}{$\begin{array}{l}\text { Disease } \\
\text { control group }(n=4)\end{array}$} & \multicolumn{3}{|c|}{ Patient group $(n=11)$} \\
\hline & Mean & $S D$ & Range & Mean & $S D$ & Range & Mean & $S D$ & Range \\
\hline $\begin{array}{l}\text { Cytochrome oxidase }(\mathrm{nmol} / \mathrm{min} / \mathrm{mg}) \\
\text { Isocitrate dehydrogenase }(\mathrm{nmol} / \mathrm{min} / \mathrm{mg}) \\
\text { Monoamine oxidase }(\mathrm{nmol} / \mathrm{hr} / \mathrm{mg}) \\
\text { Carnitine }(\mathrm{nmol} / \mathrm{mg})\end{array}$ & $\begin{array}{l}6 \cdot 31^{*} \\
11 \cdot 64 \\
3 \cdot 43 \\
4 \cdot 25\end{array}$ & $\begin{array}{l}1 \cdot 64 \\
5 \cdot 22 \\
0 \cdot 86 \\
1 \cdot 01\end{array}$ & $\begin{array}{l}4 \cdot 3-8 \cdot 5 \\
7 \cdot 4-19 \cdot 8 \\
2 \cdot 11-4 \cdot 49 \\
2 \cdot 21-6 \cdot 27 \\
(n=14)\end{array}$ & $\begin{array}{l}10 \cdot 10 \\
19 \cdot 40 \\
3 \cdot 00 \\
=\end{array}$ & $\begin{array}{l}4 \cdot 70 \\
6 \cdot 90 \\
0 \cdot 66 \\
-\end{array}$ & $\begin{array}{l}7 \cdot 2-15 \cdot 3 \\
13 \cdot 0-26 \cdot 8 \\
2 \cdot 42-3 \cdot 74 \\
-\end{array}$ & $\begin{array}{l}8 \cdot 89 \\
13 \cdot 8 \\
2 \cdot 96 \\
3 \cdot 58\end{array}$ & $\begin{array}{l}2 \cdot 58 \\
5 \cdot 94 \\
0 \cdot 80 \\
1 \cdot 01\end{array}$ & $\begin{array}{l}5 \cdot 9-13 \cdot 5 \\
7 \cdot 2-24 \cdot 4 \\
2 \cdot 17-4 \cdot 16 \\
2 \cdot 32-4 \cdot 68\end{array}$ \\
\hline
\end{tabular}

${ }^{*} p<0.05$ when compared with patient group. All other differences not significant (unpaired Student's $t$ test).

the elderly orthopaedic control group where histology was not examined.

\section{Discussion}

The patients presented in this report all had severe protracted asthenia with myalgia, both symptoms being exacerbated by exercise. The clinical features resembled patients reported as having postviral fatigue syndrome with the exception that a viral infection was never proven and only suggested on historical grounds in half the cases. The link of this syndrome to antecedent viraemia is not always proven and we prefer the designation "idiopathic chronic asthenia and myalgia syndrome" to postviral fatigue syndrome.

Patients with this disorder are generally resistant of cure both with physical and psychological treatments and are often referred to a neurologist with an interest in myology as a last resort with the question as to whether a metabolic defect in skeletal muscle is possible. The findings in this study exclude a defect in phosphorylase and all glycolytic enzymes. A major global reduction in mitochondrial activity is excluded by the normality of enzymes representing outer membrane, inner membrane and matrix activity in this study, although a very selective deficiency of a mitochondrial enzyme not measured has not been excluded. The explanation for the lower glycolytic activity found in the elderly control group is not clear. It is possible that this may reflect type $2 \mathrm{~b}$ fibre atrophy related to relative inactivity in that group and this possibility will be explored further.

The findings in this study suggest that routine muscle biopsy in the hope of pinpointing a specific metabolic abnormality is of little value in idiopathic fatigue and myalgia syndrome (post viral fatigue) and muscle biopsy should only be considered in this setting as a research procedure when novel studies are being undertaken.

The patients reported were investigated at St Vin- cent's Hospital, Melbourne, and the hospital is thanked for permission to publish clinical details. Muscle biopsies were carried out by the Neurosurgical department, St Vincent's Hospital and their assistance is acknowledged. Dr Xenia Dennett, of the Royal Children's Hospital, Melbourne, examined muscle histochemistry in all cases and her assistance is gratefully acknowledged.

\section{References}

1 Behan PO, Behan WMH, Bell EJ. The Postviral Fatigue Syndrome-an analysis of the findings in 50 cases. $J$ Infect 1985;10:211-22.

2 Epidemic Myalgic Encephalomyelitis (Leading article). Br Med J 1978;1:1436-7.

3 Henderson DA, Shelokov A. Epidemic neuromyasthenia-clinical syndrome. N Engl J Med 1959; 260:757-64.

4 McEvedy CP, Beard AW. Concept of benign myalgic encephalomyelitis. Br Med J 1970;1:11-15.

5 Easton HG. Epidemic myalgic encephalomyelitis (letter). Br Med J 1978;1:1696.

6 Byrne E. Historical and current concepts in mitochondrial myopathies. Aust NZ J Med 1983;13: 299-305.

7 Byrne E, Hallpike J, Blumberg P, Mukerjie T. Clinical features of mitochondrial myopathy. Aust $N Z \mathrm{~J}$ Med 1983;13:353-8.

8 Byrne E, Dennett X, Trounce I, Henderson R. Partial cytochrome oxidase $\left(\mathrm{aa}_{3}\right)$ deficiency in chronic progressive external ophthalmoplegia. $J$ Neurol Sci 1985;71:257-71.

9 Rowland LP, Lovelace RE, Schotland DL, Araki S, Carmel P. The clinical diagnosis of McArdles disease. Identification of another family with deficiency of muscle phosphorylase. Neurology 1966;16:93-100.

10 Layzer RB, Rowland LP, Ranney HM. Muscle phosphofructokinase deficiency. Arch Neurol 1967;17: $512-23$.

11 DiMauro SD, DiMauro M, Miranda AF. Phosphoglycerate kinase deficiency, a new cause of regur- 
rent myoglobinuria. Ann Neurol 1981;10:90-95.

12 Kanno T, Sudo K, Takeuchi I. Hereditary deficiency of lactate dehydrogenase $\mathrm{M}$ subunit. Clin Chim Acta 1980;108:267-76.

13 Arnold DL, Bore PJ, Radda GK, Styles P, Taylor DJ. Excessive intracellular acidosis of skeletal muscle on exercise in a patient with a post-viral exhaustion/ fatigue syndrome. Lancet 1984;i:1367-9.

14 Bergmeyer HV, ed. Methods of Enzymatic Analysis. Vol. II. Weinheim: Verlag Chemie, 1983.
15 Doery JCG, Hirsh J, DeGruchy GC. Platelet glycolytic enzymes: effect of cellular disruption procedures on activity. Br J Haematol 1970;19:145-57.

16 Byrne E, Dennett X, Crotty B, et al. Dominantly inherited cardioskeletal myopathy with lysosomal glycogen storage and normal acid maltase levels. Brain 1986;109 (in press).

17 Wolfson SK, Williams-Ashman HG. Isocitric and 6-phosphogluconic dehydrogenases in human blood serum. Proc Soc Exp Biol Med 1957;96:231-4. 